\title{
Aurel Stroe - Ten Years of Eternity (2008-2018)
}

\author{
PETRUȚA-MARIA COROIU \\ “Transilvania” University of Brasov \\ ROMANIA*
}

\begin{abstract}
Ten years after he passed away, Aurel Stroe remains one of the most valuable composers that Romania has offered to the world in the post-Enescu era. Belonging to an area of novelty and extreme originality of composition and musical thinking, Aurel Stroe was similarly neither understood nor appreciated enough (especially at home) and only to limited extent sung and scheduled within symphonic concerts and chamber music. But abroad, Aurel Stroe remains one of the most performed Romanian composers of modern music. Ten years after his passing away, we will attempt to create an overall view of his musical creations, and the inheritance of his composition thinking.
\end{abstract}

Keywords: composition, modernity, value, symphony, meaning.

\section{Introduction}

Although his musical creation covers almost all known genres in the history of music for this period of time, his music is difficult to interpret and understand, supposing a metaphysical education beyond the usual level required for understanding music in general. Perhaps precisely due to that, also during his lifetime, he was performed only with a work from the beginning of his career (that did not represent him in an obvious manner) within the greatest Romanian musical festival that bears the name of George Enescu.

After his passing away, the activity of interpreting his work was supported by the same groups of people, musicians and organisers who also supported it during the lifetime of the master. The relatively recent interpretation of the concert for accordion and orchestra in Bucharest remains an emblematical one (soloist Fernando Mihalache).

\section{Aurel Stroe - The concerts (1990-2001), main aesthetical ideas}

His creation includes a large variety of musical genres, represented by masterpieces. For the opera genre, we mention remarkable creations, such as: Asta nu va primi Premiul Nobel (This will not be awarded the Nobel Prize) (1969 - opera in three acts, on the libretto of Paul Sterian), Pacea [Peace] by Aristophanes (1973 - opera in three acts), Trilogia Cetății Închise [Trilogy of the Closed Citadel] (1973-1988 on the libretto, according to Aeschylus, having

\footnotetext{
*maniutpetruta@yahoo.com
} 
three parts: Agamemnon/ Oresteia I (1973), Choephoroi/ Oresteia II (1983) and Eumenides/ Oresteia III (1988), World Council (1987 - chamber opera in two acts, by the writings of Vladimir Soloviev) and Copilul și diavolul [The Child and the devil] (1989 - opera on texts by Maria Țvetaeva in 5 scenes). Theatre music: Music for "Oedipus at Colonus" (1963 - stage music for the play of Sophocles), Rituelle Handlung ohne Gegenstand (1967 - music for dancers).

Vocal-symphonic music is represented among his creations by works of remarkable value: Cantata festivă [Festal Cantata] (1957 - for mixed choir and orchestra, lyrics by Pablo Neruda), Chipul păcii [The Face of Peace] (1959 chamber cantata for mezzo-soprano, mixed choir and small orchestra with lyrics by Paul Eluard), Țării mele [To My Country] (1959 - cantata for mixed choir and orchestra with lyrics by Victor Tulbure), Monumentum I (1961 poem for men's choir and orchestra with lyrics by Nichita Stanescu), Numai prin timp timpul poate fi cucerit [Only through time can time be conquered] (1965 - poem for baritone, organ, 4 trombones and gongs, with lyrics by T.S. Eliot), Missa puerorum (1983 - for children's choir, organ and eight instruments).

Symphonic music is very well-represented among his creations, the master Aurel Stroe being a symphonist of European scope. The earliest of his creations is not very representatitve of what master Aurel Stroe was to compose at the age of maturity (Scherzo simfonic [Symphonic Scherzo] 1951, Simfonia pentru orchestră mare [Symphony for grand orchestra] - 1954, Uvertura burlescă [Burlesque Ouverture] - 1961, Arcade [Archways] - 1962, Laude I [Praises I] - 1966, Canto I - 1967, Laude II [Praises II] - 1968, Canto II - 1971, Simfonia - 1973, Accords et Comptines - 1988), because, in maturity, the change in creations presents the largest range of concepts and European musical scope: Ciaccona con alcune licenze - 1995, Preludii lirice [Lyrical Preludes] - 1999, Mandala cu o polifonie de Antonio Lotti [Mandala with a polyphony by Antonio Lotti] - 2000 .

The same situation can be also recognised with respect to concertante music, marked by significant masterpieces, in the case of placing some instruments, without a concertante tradition, in a soloist stand (which implies an exceptional originality level): Concert for string orchestra (1950, revised in 1956), Concert music for piano, brass and percussion (1965), Concert for clarinet and orchestra (1975), Concert for violin and orchestra "Capricci and Ragas" (1990), Concert for saxophone and orchestra "Prairie, Prière" (1994), Concert for accordion and orchestra (2001), and Concertante symphony for percussion and grand orchestra (1996).

Chamber music is another field in which Aurel Stroe shone in the brightest way possible, creating works or series of works left in the history of Romanian musical art: Carols for piano (1947), Ballad for piano (1948), Trio 
for oboe, clarinet and bassoon (1953), Sonata no. 1 'Morphogenetic' for piano (1955), Fragment from a sound process (1969), În vis desfacem timpurile suprapuse [In our dreams we undo overlapping times] (1970), String Quartet in A Major (1972), Grădina structurilor I [The Garden of Structures I] (1974), Ten pastoral works for organ and hapsichord (1979), Sonata no. 2 'Thermodynamic' for piano (1983), Anamorfoze canonice [Canonical Anamorphoses] (1984), Sonata no. 3 'en palimpseste' for piano (1992), and Mozart sound introspection (1994).

Choir and vocal music is represented by choirs and series of lieds, and electronic music is a field in which the master Aurel Stroe holds a pioneering role in the history of universal music for his practices used in works composed in the United States of America. Musicological writings are deep and original, although short; his thinking horizon and system can be analysed, especially through the concepts that are launched and used in his sound creation.

One of his deepest and most original concepts is the analysis of ways in which time is exposed within his musical opera: for instance, we render the situation in a work entitled În vis desfacem timpurile suprapuse [In our dreams we undo overlapping times]. The work musicalises a concept of the French philosopher Bachelard, who in his Dialectic of Duration launches the concept of a discontinuous time "the string of time is full of knots"), placed at a sound level by the co-existence of three musical works different in terms of expression, colour and dynamics, which unfold independently (but not at random), synchronised by time-keeping (devoted to the clarinet, cello, hapsichord and piano - 1970) (Bughici, 1980, pp. 15-16), creating an original counterpoint. The three levels render, at a sound level, three disparate memories from childhood:

- the folklore phenomenon perceived in childhood (transfigured in memories or dreams), represented by the presence of the clarinet, that interprets fragments close to folklore melos, of approximately 20 seconds each;

- childhood studies, that contrasted with a desire to play, represented by the presence of the piano and the hapsichord, which interpret 12 segments sung alternatively (reminding of study exercises for an instrument);

- a composition from childhood years - Apus de soare [Sunset], re-written by memory, represented by the level of the cello, that interprets a continuous and descending variation of some strict and free sequences.

This is not the only work in which the theme of time and its ways of transforming and transfiguring are approached; presenting some of them: Oresteia II (1983), Numai prin timp timpul poate fi cucerit [Only through time can time be conquered] (1965 - poem for baritone, organ, four trombones and gongs, with lyrics by T.S. Eliot); Ciaccona con alcune licenze - 1995; Mandala with a poliphony by Antonio Lotti - 2000; Concert for violin and orchestra "Capricci and Ragas" (1990); Concert for saxophone and orchestra 
"Prairie, Prière" (1994); Concert for accordion and orchestra (2001); Sonata no. 1 'Morphogenetic' for piano (1955); Sonata no. 2 'Thermodynamic' for piano (1983); and Sonata no. 3 'en palimpseste' for piano (1992).

The musicological work we now forward through these words contains the analytical effort oriented towards the most important ideas of the last three concertos composed by Aurel Stroe (chronologically situated in the composer's last decade of creation, testimonies of the newest conceptions launched by him). Proof of his compositional maturity, the three concertos belong to the same musical genre, even if the Concerto dedicated to the saxophone has a more likely dramaturgic profile which resemble more to a concertingsymphony than to a concerto.

As well, the fact that they belong to this last years of the composer's life makes these three concertos be the proof of a syntheses specific to the completing of a career, syntheses that has resonances in a spiritual dimension difficult to evaluate and to assimilate. That is why it has been imposed the configuring of the dramaturgy of the musical discourse, an internal ideal procession developed in the frame of the comprehensive reality of the personality of the one who carries the responsibility of creating.

The last three concertos from the Aurel Stroe's creation were composed between 1990 and 2001: the Concerto for violin solo and soloists ensemble, the Concerto for saxophone and grand orchestra and the Concerto for accordion and soloists ensemble. These works can provide a unitary view on the stylistic characteristics of Aurel Stroe's symphonic thinking.

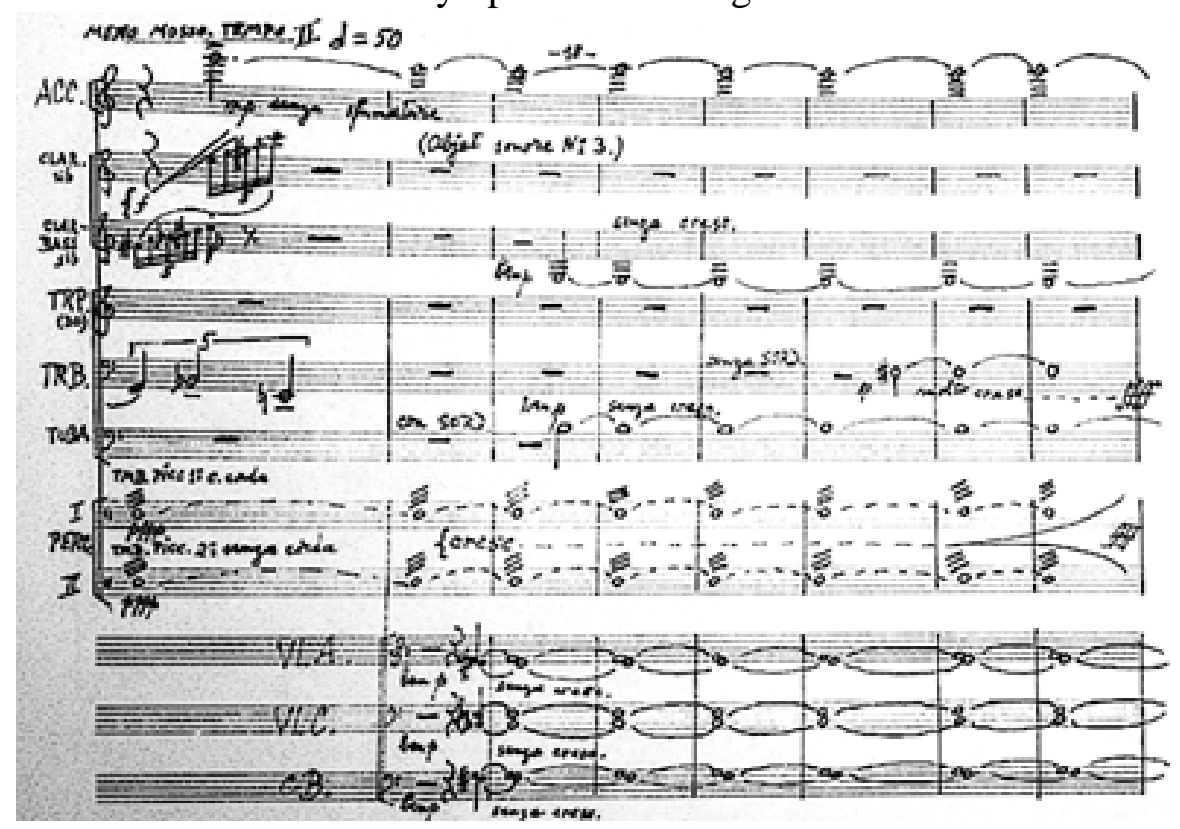

Fig. 1 Aurel Stroe, Concerto for violin and soloists ensemble (Paganiniana I) 
The Concerto for violin and soloists ensemble is the first one in the works belonging to the genre analyzed in this work; it has been finalized in Mannheim, at 11 July 1990, being the first one from the series which we will analyze in this work which includes the last three concerting works of Aurel Stroe. Just from the beginning one can notice the structuring of the concerto in six movements which through the grouping suggested by their alternation, they constitute in fact three sonorous beings with a double meaning: "Paganiniana" şi "Ecoute fine".

The main problem in this concerto is its esthetic, stylistic, spiritual resistance, at the pressures imposed by the vicinity of some incommensurable terms, in a work with many cultural paradigms (the European one, represented in the violinist patrimony by Paganini's "Caprices", and in the oriental one embodied by ragas, performed at some "exotic instruments"). We consider that the consequences at the sonorous level are impressive, being observed processes of intercontamination between the two spheres of values, which leads in the final part of the concerto toward its stylistic collapse.

The Concerto for saxophone and grand orchestra "Prairie, priers" represents the expression of a new vision on the symphonic thinking with a concerting specific in the musical frame of the XXth century. The inauguration of this original conception was produced in the same time with the emergence of the Concerto for clarinet and orchestra, which modifies the main developing coordinates of the instrumental discourse with orchestral accompaniment.

The author mentioned that it is a concerting symphony for saxophone and grand orchestra. The Concerto is impressive through its technique and stylistic way of artistic realization, and most of all through the intimate atmosphere that it induces and which is sonorous externalized. The concert sonorously transposes the individual expressive paroxysm, brutally estranged of his usual condition, through a non-evolving discourse, which surprises the listener by his position outside the symphonic XXth century customs.

The first movement of the Concerto (entitled “... des forms naissent dans un milieu homogene.....”) contain the following programmatic sections: Multimobile - Prairie 1 - La Carnaval d'Arlequin - Prairie 2 (fact that entitle us to have analytical micro-sections dedicated to the intercontextuality, polyphony and the superpostional complexity, as well as on the manieristic symbols).

The second section represents the re-exposition "through rarifying" (reprise par rarefaction) of the Multimobil (in the hypostasis of a phenomenon of degradation of the musical discourse), and the last three parts are organized on a superior level of instrumental expressivity: "Ascension vers une melodie lontaine" (the sonorous metaphor of the composer's spiritual ideal), then "Un reste non assimile: Ondine" (where appears the stylistic dissolution, the disconcert of thinking, the destabilizing of the superficial/apparent equilibrium) 
and a last "Un dernier reste" (the ending of an open opera, whose last part is in fact the moment of a continuous semantic communication, the break between levels, between the objective and the semantic levels).

The Concerto for accordion and orchestra is a state order and it is dedicated to an soloist instrument with a insignificant concert tradition, especially in the main appearance: the accordion, having as a accompanying gesture of an ensemble of soloists. Forwarded by the word of the French writer Francis Ponge, (“... entre le glorieux et le bizzare, une certaine proportion...”), the concert illustrates the catastrophical morphogenetic moment - the time of confession which remains - always-unrevealed.

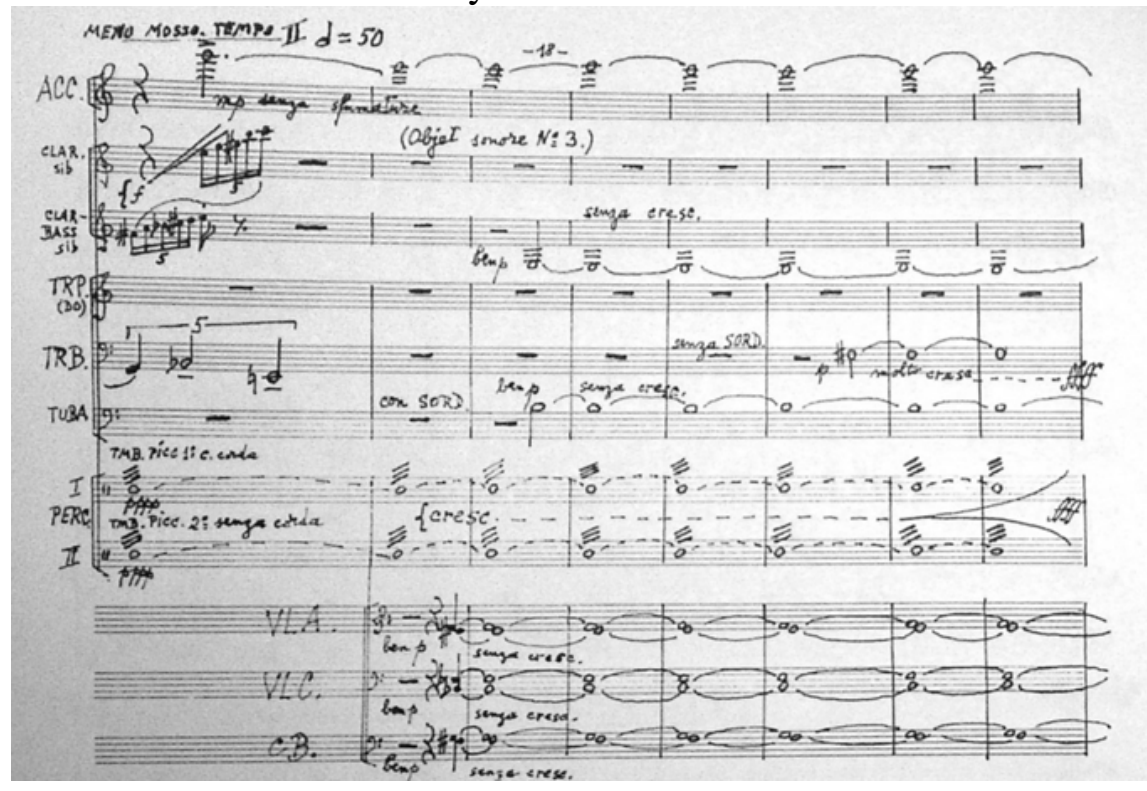

Fig. 2 Aurel Stroe, Concerto for accordion and orchestra (sound object)

This is the expressive enigma of the rupture to which Aurel Stroe has appealed so often. The first movement, ("Cinq petits chorals (et une invention) en hommage pour Erik Satie"), permits us the outlining of a compendium of the types of the harmonic disposal, integrated in the miniature musical forms (with special references regarding the evolution of the concepts of "consonance" and "dissonance", the harmonic archetype importance and to the structural consequences of the interruption of the chorals by the invention).

The other movements of the Concerto are "Fugue dissipative" (which illustrates the morphogenetic break from the structural level of the work) and "Accord-Matrice" (the harmonic synthesis of the stylistic archetype of the work) and "Multimobile et Boucles". 


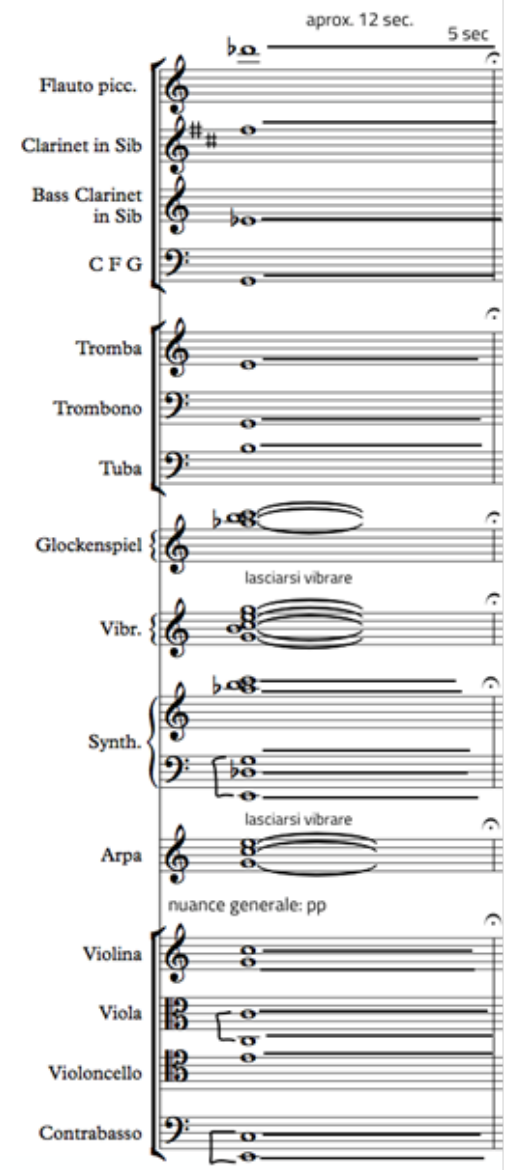

Fig. 3 Aurel Stroe, Concerto for accordion and orchestra (accord-matrice)

Our musicological approach has been facilitated by the permanent contact in the last ten years established with the author, one of the most important creators of the Romanian culture in the XXth century; more than a mere composer, Aurel Stroe is a thinker free of his own thoughts, a musician free of his own personality; the phenomenon can have severe consequences in the ulterior performance of the art of another culture creator; the conceptual brakes, free from the strict control of the creative consciousness - could crumble the construction which support a major act, with multiple artistic resonances.

As we can see, the programmatic dimension of Aurel Stroe's music is present, being the composer who sees ideas, materializing ideas in his music under the most diverse names: "Peter Kivy claims that there is a clear opposition between 'absolute music' and programme music and between musical form and musical expressiveness. But much music falls somewhere 
between absolute and programme music [...] and that such music is often primarily organized not on purely formal principles but by means of the overall expressive trajectory or poetic idea of the piece” (Robinson, 2015, pp. 23).

\section{Conclusion}

"His music was not just a symptom of our time (like other genius works), it was also an examination and a critique of her, a cry out of the very disintegration of the traditional musical ontology. [...] Aurel Stroe was highly educated not only in music, but also in sciences. In his courses, the references in mathematics and physics were not rare, and the philosophical framing of the themes he had was obligatory. He did not use these ornamental references, but with a cognitive, exploratory purpose. In his lectures, the world became a world, and well-tempered culture and sensitivity were the normal way of access. This formidable intelligence was, must be said, engaged. Engaged in ethics, in character, in the belief that the ultimate justification of the world is not at all aesthetic but ethical and religious.” (Patapievici, 2008)

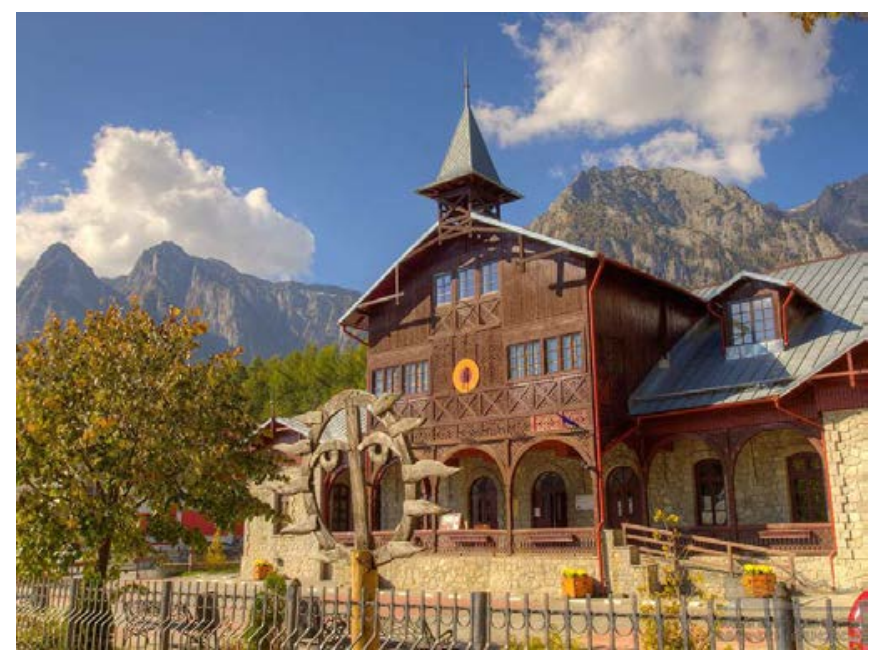

Fig. 4 Centrul cultural Aurel Stroe din Busteni, Jud. Prahova, Romania

There can be thus sketched the general coordinates of an entire typology of sceneries which animate, in an unique way, each work of art. We can establish, in the end, which are the most used means of transferring in music the composer's inner universe, through these it could become communicable. The goal of our studies is the strictly compositional travail only as it supports the superior, spiritual level of an opera.

Aurel Stroe remains, in the ten years since his passing to the eternal life, one of the most valuable composers that Romania offered to the world in the Enescian post-generation. Enrolling in an area of novelty and extreme 
originality of compositional and musical thinking, Aurel Stroe was equally unintelligible and unappreciated, rather unappreciated (more at home), insufficient scheduled in concerts or chamber recitals.

Outside the country's borders, Aurel Stroe remains one of the most loved and sophisticated Romanian authors of modern music. Ten years after its passing to the eternal, we still try to create an overall picture of his musical heritage, of his creation and of his componential thinking.

\section{References}

Bughici, D. (1980). Particularităţi ale formelor muzicale, II [Particularities of musical forms]. Muzica, 2, București.

Patapievici, H. R. (2008). O inteligență angajată [A committed intelligence], retrieved from https://evz.ro/patapievici-o-inteligenta-angajata-823406.html

Robinson, G. (2015). Yet Again, Between Absolute and Programme Music. In The British Journal of Aesthetics, 55, 1, 19-37. Oxford University Press. 